$11-3-2020$

\title{
Large Projected Population Loss of a Salt Marsh Bivalve (Geukensia demissa) from Sea Level Rise
}

\author{
Robert Isdell \\ Virginia Institute of Marine Science \\ Donna M. Bilkovic \\ Virginia Institute of Marine Science \\ Carlton Hershner \\ Virginia Institute of Marine Science
}

Follow this and additional works at: https://scholarworks.wm.edu/vimsarticles

Part of the Marine Biology Commons

\section{Recommended Citation}

Isdell, Robert; Bilkovic, Donna M.; and Hershner, Carlton, Large Projected Population Loss of a Salt Marsh Bivalve (Geukensia demissa) from Sea Level Rise (2020). Wetlands.

doi: 10.1007/s13157-020-01384-4

This Article is brought to you for free and open access by the Virginia Institute of Marine Science at W\&M ScholarWorks. It has been accepted for inclusion in VIMS Articles by an authorized administrator of W\&M ScholarWorks. For more information, please contact scholarworks@wm.edu. 
2 rise

3 Robert E. Isdell $^{1 *}$, Donna M. Bilkovic ${ }^{1}$, Carlton Hershner ${ }^{1}$

$4 \quad{ }^{1}$ Virginia Institute of Marine Science, William \& Mary, Gloucester Point, VA 23062

$5 \quad$ *risdell@,vims.edu

$7 \quad$ Abstract

8 Salt marshes and their inhabitants are being displaced by climate change and human

9 development along the coastline. One inhabitant, the ribbed mussel (Geukensia demissa), forms

10 a mutualistic relationship with smooth cordgrass, Sporobolus alterniflorus, along the US Atlantic

11 Coast. Ribbed mussels stabilize the marsh, remove particulate matter from the water column, and

12 promote denitrification, thereby improving local water quality. To quantify the potential effects

13 of SLR on ribbed mussel abundance and resulting impacts on water quality functions, we

14 compared the current and projected future (2050) spatial distributions of ribbed mussels in

15 Chesapeake Bay assuming an intermediate SLR for the region. We found that ribbed mussel

16 abundance was reduced by more than half due to a combination of drowning marshes, coastal

17 squeeze, and a shift from higher to lower quality habitat. Mussel losses were greatest along the

18 mainstem of the Chesapeake Bay, with modest gains in the headwaters. Our results highlight the

19 importance of permeable land cover (including living shorelines) in the future tidal extent to

20 promote marsh transgression for future mussel populations. The projected mussel abundance

21 reductions will result in a $>50 \%$ reduction in mussel-mediated filtration and nitrogen processing,

22 ultimately reducing the resilience of marshes in the system. 


\section{INTRODUCTION}

Along the salt marshes of the United States Atlantic Coast, ribbed mussels, Geukensia

25 demissa (Dillwyn 1817), form a mutualistic relationship with Sporobolus alterniflorus (Loisel.;

26 henceforth cordgrass). Cordgrass provides habitat for the ribbed mussel in several ways. First,

27 cordgrass stems promote particle trapping by acting as baffles in the water (Leonard and Croft

28 2006). Ribbed mussel larvae are sufficiently small (Loosanoff and Davis 1963, Baker and Mann

292003 ) to be influenced by the viscosity dynamics that dominate the behavior and transport of

30 particles with low Reynolds numbers (i.e., particle sizes at which a fluid becomes viscous) in

31 water (Scheltema 1986, Vogel 1994). Like large sediment grains, ribbed mussel settlement is

32 facilitated by the low-flow environment created by cordgrass marshes. Once settled, the shade

33 provided by an extensive canopy of cordgrass reduces thermal and desiccation stress, which

34 enhances mussel metamorphosis and survival (Bertness 1984). Ribbed mussels burrow into the

35 sediment of salt marshes where they attach to the roots, rhizomes, and stems of the cordgrass

36 with their byssal threads, which binds the sediment, reduces erosion, and increases the stability

37 of the marsh (Bertness 1984, Bertness and Leonard 1997). The mussels filter considerable

38 amounts of water (Wright et al. 1982, Kreeger and Newell 2001, Moody and Kreeger 2020a),

39 excrete ammonium, and deposit nutrients on the surface and subsurface of the marsh in their

40 feces and pseudofeces (Jordan and Valiela 1982). These excretions fertilize the sediment and

41 promote vegetation growth in a positive feedback loop, increasing shade and particle trapping,

42 and thus mussel recruitment and marsh accretion.

43 Within salt marshes, ribbed mussels are capable of providing a wealth of ecosystem

44 services. These filter feeders are capable of clearance rates $\left.\left(L \cdot h^{-1}\right)\right)$ on par with oysters $($ Kreeger

45 and Newell 2001), and effectively remove a wide size-range of particulate matter. Compared to 
oysters, ribbed mussels are exceptional in their ability to filter bacteria from the water column,

47 making them especially valuable for improving water quality issues (Wright et al. 1982, Kreeger and Newell 2001). Through the process of filtration, ribbed mussels ingest particulate nitrogen

$49(\mathrm{~N})$, which they subsequently assimilate to their tissues, and deposit excess particulates and waste on the surface and subsurface of the marsh (Jordan and Valiela 1982). Mussels also

51 enhance denitrification when they co-occur with cordgrass, resulting in higher $\mathrm{N}$ removal from

52 the system than either could achieve separately (Bilkovic et al. 2017). Stabilizing and fertilizing

53 the sediment increases the resilience of the marsh (Angelini et al. 2015, 2016) by reducing

54 erosion and promoting shoot growth (Bertness 1984), thereby enhancing the marsh's ability to

55 protect the upland during storm events (Schuerch et al. 2013). Mussels, however, are not

56 homogeneously distributed across the marsh surface (Bertness 1984, Franz 2001, Julien et al.

57 2019, Moody and Kreeger 2020b). Throughout much of their region, mussels are densest on the

58 front (waterward) edge of the marsh where they can achieve numbers in excess of 5,000

59 individuals per $\mathrm{m}^{2}$ (Bertness and Grosholz 1985, Bilkovic et al. 2017). We have previously

60 developed a mussel distribution model that identified the primary factors influencing abundance

61 and distribution along the front edge of cordgrass marshes (Isdell et al. 2018). These factors

62 included cordgrass stem density, wave exposure, and forested and agricultural land covers. High

63 exposure marsh edges with dense cordgrass and minimal nearby forest were identified as high-

64 quality mussel habitat.

65 Marshes around the world are rapidly changing in response to sea level rise (SLR),

66 erosion, and human development. As the planet continues to warm as a result of anthropogenic

67 releases of greenhouse gasses, melting land ice, thermal expansion, glacioisostatic rebound, and

68 other local factors are raising the sea level (IPCC 2014). As SLR continues and accelerates 
69 (Boon 2012), salt marshes will struggle to maintain their vertical position within the tidal frame

70 (Mitchell et al. 2017). While there are mechanisms for marshes to keep apace of SLR, in many

71 regions, the rate of SLR is expected to exceed the rate that marshes can sustainably accrete,

72 resulting in marsh loss (Mitchell et al. 2017). Erosion is also playing a key role in the

73 transformation of marshes through coastal squeeze - the process by which the front edge of the

74 marsh is receding at a greater rate than the back (landward) edge is moving inland due to sea

75 level rise (Pontee 2013). Coastal squeeze can be the result of both natural and human causes

76 (Doody and Williams 2004, Torio and Chmura 2013). Natural causes include an increasing slope

77 at the landward edge of the marsh, which decreases the potential rate of inland migration

78 (Fagherazzi et al. 2019). Humans can also engineer sudden changes in slope/elevation at the back

79 of a marsh by building shoreline protection structures such as riprap or bulkhead. These

80 structures are designed to reduce erosion, but also create a physical barrier that impedes

81 landward migration of the marshes. Eventually, marshes caught between these structures and a

82 rising sea are likely to disappear entirely.

83 Like many urban estuaries around the world, the Chesapeake Bay has long been plagued

84 by water quality issues caused by human disturbances and activities (Kemp et al. 2005). Decades

85 of intense agricultural and urban runoff into the numerous tributaries of the Chesapeake Bay

86 resulted in a highly eutrophic system and the development of an annual dead zone (Diaz and

87 Rosenberg 2008). The loss of wildlife and commercially valuable species, in addition to the poor

88 water quality, led to the establishment of several agreements between the states within the

89 Chesapeake Bay watershed and the US Environmental Protection Agency (EPA) to reduce the

90 input of nutrients from a variety of sources (Linker et al. 2013). Due, in part, to the limited

91 success of these agreements and the continued water quality issues of the Bay, in 2010, the EPA 
92 established Total Maximum Daily Loads (TMDLs) for each sector of the Bay which requires

93 states to meet the goals in accordance with the Clean Water Act (US Environmental Protection

94 Agency 2010).

95 Accounting for the water quality improvement capacity of wild populations of shellfish is

96 important for accurate assessments and planning to meet water quality goals. To date, very few

97 management plans have incorporated standing or projected stocks of wild shellfish as water

98 quality mediators despite their proven potential (for example, see USACE 2014). Oysters have

99 long been promoted for their water quality improvement potential (Kellogg et al. 2014), and

100 numerous studies have documented their ability to remove particulate organic and inorganic

101 matter from the water column, improving visibility and reducing nutrients (Grabowski et al.

102 2012, Ermgassen et al. 2013). Ribbed mussels, in contrast, have received limited attention for

103 their ability to remove nutrients and improve water quality on a large scale (Galimany et al.

104 2017, Kreeger et al. 2018). One of the limiting factors for this is the lack of understanding of the

105 spatial distribution of ribbed mussels within estuaries. With only a handful of published

106 estimates of ribbed mussel abundance in any large system (i.e., beyond the scale of a marsh; see

107 Honig et al. 2015, Bilkovic et al. 2017, and Moody and Kreeger 2020b), their overall

108 contribution to water quality is largely unknown. As such, we have the following objectives for

109 this study: 1) to simulate future mussel abundance and distribution under projected sea level rise

110 in the lower Chesapeake Bay, 2) to compare current and modeled future mussel distribution, and

1113 3) to estimate changes to mussel-mediated nutrient removal and water filtration because of

112 mussel population shifts, and the implications for water quality in the Bay. We hypothesize that

113 ribbed mussel abundance in the Chesapeake Bay is likely to decrease as marshes are also

114 expected to decrease in the future due to drowning and coastal squeeze (Mitchell et al. 2017). We 
115 expect these losses to be greatest in urban areas where extensive armoring and high exposure

116 have accentuated the conditions necessary for coastal squeeze, and that ribbed mussel-mediated

117 ecosystem services will also be similarly impacted.

118 METHODS

119 Study area and site selection

120 The study area included cordgrass-dominated marshes along $\sim 6,700 \mathrm{~km}$ of shoreline

121 (Center for Coastal Resources Management (CCRM) 2018) within Virginia's microtidal ( $1 \mathrm{~m}$;

122 Boon and Mitchell 2015) waters of the Chesapeake Bay that fell within the physiological salinity

123 tolerances of ribbed mussels ( $\geq 8 \%$; Lent 1969, Julien et al. 2019).

$124 \quad$ Mussel model

125 The current distribution and abundance of mussels along the front edge of the marsh (first 126 two meters perpendicular to the water) was taken from Isdell et al. (2018), while the future

127 mussel abundance was estimated using the Mussel Distribution Model (MDM) described within.

128 The specific model is provided below (Eq. 1):

$$
\log \left(y_{i}\right)=0.5337+0.0363 x_{1 i}+0.0125 x_{2 i}-0.0133 x_{3 i}+0.0009 x_{4 i}
$$

Eq. 1

130 where $y_{i}$ is the density of mussels (individuals $\left.\cdot \mathrm{m}^{-2}\right), x_{1 i}$ is the cordgrass stem density $\left(\mathrm{stems} \cdot \mathrm{m}^{-2}\right)$,

$131 x_{2 i}$ is the percent water within a $300-\mathrm{m}$ radius of a point along the shoreline (used as a proxy for

132 exposure; referred to as exposure henceforth), $x_{3 i}$ is the percent forest within a 60-m radius of a

133 point along the shoreline, and $x_{4 i}$ is the percent agriculture within a $300-\mathrm{m}$ radius of a point along 134 the shoreline.

135 Several surveys have suggested that the vast majority $(\sim 85 \%)$ of mussel biomass within a

136 marsh resides in the front edge of the marsh (Bertness 1984, Franz 2001, Bilkovic et al. 2017 ,

137 Isdell et al. 2018), and modeling the edge will provide the greatest insight into potential changes 
138 in mussel distribution. Spatial application of the MDM was completed in ArcMap v. 10.4.1

139 (ESRI 2017) using the raster calculator tool. Land use/land cover (LULC) data were derived

140 from the VGIN $1 \mathrm{~m}$ Land Cover dataset (2016; https://bit.ly/2HwWWcy) and resampled to 5-m

141 resolution using the "Resample" tool and majority technique. Moving window analyses were run

142 using the "Focal Statistics" tool at the corresponding scale (e.g., forest at $60 \mathrm{~m}$ ) for each LULC

143 type. Cordgrass stem density was held constant at a mean density (224 stems $\mathrm{m}^{-2}$; derived from

144 surveys conducted in Isdell et al. 2018) to allow for spatial application throughout the study area.

145 Future marsh and mussel extent

146 Future marsh extent was derived from work done by Mitchell et al. (this issue). To set a

147 timeframe for shifts in elevation in the tidal frame, a sea level rise projection curve based on data

148 from the Sewell's Point, Virginia tide gauge was used, which suggests a 0.58 -m increase in sea

149 level by 2050 (Boon et al. 2018). Sea level rise projections vary minimally across the Virginia

150 portion of the Chesapeake Bay (Ezer and Atkinson 2015), and Sewell's Point is considered

151 representative of overall trends (Boon et al. 2018). The vegetated tidal marsh frame in the

152 Chesapeake Bay falls in the elevation range between mean sea level to highest astronomical tide,

153 considered to be a 0.61-m envelope in this analysis across the Chesapeake Bay, Virginia

154 (Mitchell et al. this issue). Appropriate elevations encompassed in the tidal marsh frame

155 projected for 2050 were selected from a LiDAR-based digital elevation model (DEM;

$156 \mathrm{https} / / / \mathrm{goo} . \mathrm{gl} / 2 \mathrm{djptg}$ ). Land use data in the projected 2050 tidal frame were selected from the

157 VGIN $1 \mathrm{~m}$ Land Cover dataset (2016). To approximate future mussel habitats, marsh migration

158 was permitted into all pervious surfaces other than actively managed forests or turf on the

159 assumption that these areas would be protected with some form of structure to prevent loss.

160 Further, marsh migration was restricted from moving beyond existing barriers such as shoreline 
161 armoring. Erosion was incorporated into the future extent by multiplying spatially explicit

162 known average annual erosion rates reported in Hardaway et al. (2017) by 32 (the number of

163 years between 2018 and 2050) to estimate where the shoreline would be in 2050 . The annual

164 erosion rates reported in Hardaway et al. (2017) were calculated as the horizontal change in

165 shoreline location divided by the number of years between the imagery on which the shorelines

166 were based. Given that many locations had a timespan $>10$ years between measurements, these

167 rates incorporate the stochastic processes that result in variable erosion rates.

168 Mussel abundances in 2050 were estimated by adjusting predictive factors to reflect

169 future conditions and applying the MDM to the projected future marsh distribution under sea

170 level rise. The water layer was recreated to incorporate the erosion and landward migration of the

171 marshes. The other predictors (cordgrass density, agriculture, and forest) were held constant

172 because there are no available spatially-explicit estimates of how these factors will change by

173 2050. All area below the future tidal envelope estimated by Mitchell et al. (this issue) was

174 considered to become subtidal and categorized as water. Segments of estimated 2050 shoreline

175 that were $>175 \mathrm{~m}$ inland from their current position were excluded from the analysis due to

176 erosion rates in excess of $5 \mathrm{~m} \mathrm{y}^{-1}$ being too great to support a viable edge population of mussels

177 (Isdell, unpublished data).

178 Zone of inference

179 We selected 12-digit hydrologic unit codes (HUCs; Henley 2006) as our zones for spatial

180 inference (Figure 1). The 12-digit HUCs provide small-scale delineations of watersheds

181 primarily at the level of small rivers or large tidal creeks, rather than political boundaries. This

182 allows for a large, yet still localized approach to our analysis. We modified the shapefile

183 provided by USGS (Henley 2006) by splitting HUCs that spanned both shores of the major rivers 
184 (James, York, and Rappahannock Rivers) down the center of the channel. Our modeled estimates

185 of mussel distribution fell within $80 \mathrm{HUCs}$, which were selected for further summaries. Within

186 each HUC, we summarized the LULC data for agriculture, forest, impervious surface, and

187 wetlands that fell within the 2050 tidal envelope, as well as the whole HUC. The total abundance

188 of mussels in 2018 and 2050, as well as the total area of marsh edge habitat at each time were

189 summarized for each HUC using QGIS 3.8.3 (QGIS Development Team 2019).

190 Statistical analyses

191 Watersheds were categorized by loss vs. gain for summary statistics. Land cover

192 characteristics were used to develop a recursive regression tree (package 'rpart'; Therneau et al.

1932018 ) which was pruned to keep only nodes with a complexity parameter $>0.1$. All statistical

194 analyses were completed using R (R Development Core Team 2018).

195 Filtration and Nitrogen Processing Calculations

196 We used literature derived estimates for mussel filtration, biodeposition, and

197 denitrification rates (Table 1). We assumed 12 hours per day for filtration and biodeposition on

198 the basis of average marsh edge inundation frequency (mussels at the front of the marsh are

199 approximately at mean sea level, and the Chesapeake Bay has a semi-diurnal tidal cycle), and 24

200 hours per day for denitrification. All rates were dependent on biomass (g dry tissue weight). For

201 our calculations, we used the median dry tissue weight per mussel $(0.26 \mathrm{~g})$ derived from $>1,000$

202 mussels collected around the study area by Isdell et al. (2018), multiplied by the predicted

203 number of mussels per $\mathrm{m}^{2}$. The use of a static feeding time and single median biomass without

204 taking population-level size demographics into consideration is a limitation of the approach, but

205 unfortunately necessary given that we do not have population-level size demographics for ribbed

206 mussels in the Chesapeake Bay, nor do we have how demographics vary throughout the Bay. 
207 This information would provide significant improvements to the estimates, but was unavailable

208 at the time of this publication. All rates were transformed to the expected annual contribution per

209 watershed. We compared our estimates of service changes and nitrogen removal capacity with

210 the established targets of the TMDLs set forth by the EPA.

\section{RESULTS}

212 Among the 80 watersheds examined, total mussel abundance decreased from 805 million

213 in 2018 to 314 million in 2050. Losses were observed in 67 of the watersheds (mean $=-7.70 \pm$

2141.18 million mussels) and gains were observed in 13 (mean $=2.76 \pm 1.04$ million mussels), with

215 a system-wide range of $-47-+14$ million mussels (Figure 2). Increases primarily occurred where

216 creeks widened as a result of coastal squeeze reducing extensive marsh areal extent, but still had

217 enough permeable land cover in the uplands to support a greater length of fringing-marsh edge

218 (Figure 3), with minor contributions coming from the conversion of formerly-interior high marsh

219 fragmenting into high-quality low marsh edge habitat.

220 Spatially, relative decreases were greatest in the southern and northeastern portions of the

221 Bay (Figure 4), while increases were diffuse among the upper reaches of the tributaries. The

222 distributions of relative and absolute differences were similar overall, with the ultimate result

223 being low abundances of mussels $(<5$ million per HUC) through almost the entire study area.

224 The largest absolute losses were in HUCs with large, extensive marsh complexes where

225 drowning led to edge retreat in excess of $5 \mathrm{~m} \cdot \mathrm{y}^{-1}$ (see bright red HUCs in Figure 4A). The

226 primary exception to the overall trend of loss was within the HUC encompassing Jamestown

227 Island, which saw an increase of 14 million mussels by 2050 - an approximately $100 \%$ increase

228 over current numbers. This HUC has an upland in close proximity to the current shoreline with

229 considerably greater complexity (i.e., linear distance) than the comparatively simple marshes that 
currently line the waterways (Figure 3). The regression tree identified 3 primary nodes to explain

231 the relative change in ribbed mussel abundance (Figure 5). Watersheds with $<28 \%$ forested land

232 cover in the future intertidal zone had the largest loss of mussels $(-58 \% \pm 17 \%)$, while

233 watersheds with $>28 \%$ forested, $1 \%$ agricultural, and $36 \%$ marsh land cover in the future

234 intertidal zone had the greatest potential for gains $(69 \% \pm 72 \%)$.

235 Given that filtration rates and nitrogen processing are directly tied to ribbed mussel

236 biomass, we also expected a net loss of services throughout Virginia. On average, regions that

237 gain mussels will filter an additional $6.3 \pm 2.4$ gigaliters $(\mathrm{GL}) \cdot \mathrm{y}^{-1}\left(\operatorname{range}<0.1-32.6 \mathrm{GL} \cdot \mathrm{y}^{-1}\right)$,

238 produce $173.2 \pm 65.3 \mathrm{~kg} \mathrm{~N} \cdot \mathrm{y}^{-1}$ (range $0.5-900.7 \mathrm{~kg} \mathrm{~N} \cdot \mathrm{y}^{-1}$ ) of additional biodeposits, and remove

239 an additional $81.3 \pm 30.7 \mathrm{~kg} \mathrm{~N} \cdot \mathrm{y}^{-1}$ (range $0.2-422.9 \mathrm{~kg} \mathrm{~N} \cdot \mathrm{y}^{-1}$ ) via denitrification (Figure 6). In

240 contrast, regions that lose mussels will filter $17.9 \pm 2.8 \mathrm{GL} \cdot \mathrm{y}^{-1}\left(\right.$ range $\left.-106.2--0.1 \mathrm{GL} \cdot \mathrm{y}^{-1}\right)$ less

241 water, produce $493.2 \pm 76.1 \mathrm{~kg} \mathrm{~N} \cdot \mathrm{y}^{-1}$ (range $-2,928.5--1.8 \mathrm{~kg} \mathrm{~N} \cdot \mathrm{y}^{-1}$ ) fewer via biodeposits, and

242 remove $231.6 \pm 35.7 \mathrm{~kg} \mathrm{~N} \cdot \mathrm{y}^{-1}$ (range $-1.374 .9--0.9 \mathrm{~kg} \mathrm{~N} \cdot \mathrm{y}^{-1}$ ) via denitrification. The direct link

243 between mussel abundance and services provided means that the spatial redistribution of those

244 services follows suit.

245 We compared changes in nitrogen processing capacity between the present and future

246 mussel populations to the TMDL targets for the Commonwealth of Virginia (Northam and

247 Strickler 2019). Compared to the 2025 TMDL goal for $\mathrm{N}$ inputs $\left(25.28 \times 10^{6} \mathrm{~kg}\right)$, we estimate

248 that mussels along the edge of marshes are currently able to process $0.18 \%\left(46.27 \times 10^{3} \mathrm{~kg}\right) \mathrm{of}$

249 nitrogen loading in Virginia through biodeposition and denitrification each year. However, by

2502050 , mussels along the marsh edge will only be able to process $0.07 \%\left(18.03 \times 10^{3} \mathrm{~kg}\right)$ of the

251 annual $\mathrm{N}$ inputs in Virginia. 
Ribbed mussel populations are likely to drop precipitously in the Chesapeake Bay as a result of SLR. As relative sea level rise (RSLR) continues to accelerate (Mitchell et al. 2018), 256 many marshes will be unable to vertically accrete to maintain their current areal extent. The 257 resulting drowning and erosion will result in marshes that change too quickly to support adult 258 populations of ribbed mussels and/or shift toward lower-quality habitat for ribbed mussels 259 throughout the Bay. While some of the effects will be tempered by marsh migration, the data do 260 not support this mechanism to be a viable option for long-term sustainment of the ribbed mussel 261 population as coastal squeeze will intensify as marshes continue to migrate landward. The 262 reduction in the ribbed mussel population will result in proportional reductions in the ecosystem 263 services they provide, such as nutrient removal, water filtration, and marsh stabilization. Losing nearly 500 million ribbed mussels throughout Virginia’s Chesapeake Bay will 265 negatively impact the resilience of the system in the face of climate change. Even if marshes are 266 able to maintain their acreage by migrating into the adjacent uplands, the rate of change along 267 the edge of the marsh where mussels are densest is likely to exceed what mussels are able to 268 keep up with, particularly in watersheds with extensive marsh complexes. We noted projected 269 erosion/transgression rates in excess of $5 \mathrm{~m} \cdot \mathrm{y}^{-1}$ in several of the regions with extensive marsh 270 complexes where the topography was exceptionally flat. These also tended to be the same 271 regions where current mussel populations are at their highest due to the large amount of high272 quality habitat. Given that mussels are densest along the edges of marshes, with about $85 \%$ of the 273 population occurring within the first two meters of the marsh in Virginia (Bilkovic 2017, Isdell et 274 al. 2018), erosion rates that exceed $5 \mathrm{~m} \cdot \mathrm{y}^{-1}$ will prevent the vast majority of new recruits from 275 reaching maturity, which takes at least one year (Franz 1996). Even assuming an annual 
276 recruitment rate of $100 \%$, this is not a sustainable rate of change, and will rapidly reduce the

277 adult population that exists beyond the first $5 \mathrm{~m}$ to a point where they may not be able to produce

278 enough larvae to maintain the population. We argue that simply using change in marsh acreage

279 as a metric of how a region is responding to sea level rise is inadequate to capture the importance

280 of edge habitats and processes, in which ribbed mussels play an integral role.

281 This study highlighted the importance of permeable land cover within the tidal frame for

282 facilitating the inland migration of marshes and the perpetuation of ribbed mussel habitat.

283 Greater quantities of forested, agricultural, and marsh land cover within the future tidal frame

284 were important for mitigating the loss or even increasing the population of ribbed mussels within

285 the Chesapeake Bay. Numerous other studies have documented the importance of permeable

286 land cover for the inland migration of marshes (Mitchell et al. 2017, Scheider et al. 2017). While

287 impervious surfaces weren't to blame for the substantial predicted losses in watersheds with

288 expansive marsh complexes, they are a limiting factor in more urbanized settings. Coastal

289 squeeze ultimately results in the loss of marsh habitat (Pontee 2013) and is exacerbated by

290 human development. To sustain marshes and ribbed mussel habitat in urban areas, large-scale

291 implementation of green infrastructure, such as living shorelines, coupled with managed retreat

292 for inland marsh migration may be helpful. Local extirpation of an important bivalve will lead to

293 lower water quality and ecological resilience in already heavily impacted areas. Note, however,

294 that even these strategies will face the same stresses as natural marshes in the face of accelerating

295 SLR, and may require regular maintenance and interventions (such as additions of sediment to

296 increase marsh elevations) to sustain the marshes.

297 The projected changes in ecosystem services may have significant effects on the

298 attainment of water quality goals at local scales. Despite a removal capacity of $<1 \%$ of the total 
nitrogen inputs to Virginia as a whole, the first two meters of a marsh represent a very small

300 amount of the area in these watersheds. This results in a dense concentration of $\mathrm{N}$ removal

301 potential and filtration capacity, making the ribbed mussel/cordgrass partnership along the marsh

302 edge highly valuable per unit area for these services. Further, watersheds that currently have

303 large abundances of mussels could be meeting much larger proportions of their TMDL targets

304 via ribbed-mussel-mediated ecosystem services than the overall state average. For example,

305 ribbed mussels in Accomack County (NE corner of the study area) are currently removing

306 enough $\mathrm{N}$ to account for $10 \%$ of their 2025 TMDL target. By 2050, we expect that the ribbed

307 mussel population will only be able to remove $4 \%$ of $\mathrm{N}$ inputs to the system. This reduction in

308 ribbed mussel-mediated N-removal means greater reliance on implementing additional best

309 management practices, increasing set-back distances, and improved ground water, surface water,

310 storm water, and sewage management to compensate for the lost ecosystem services provided by

311 ribbed mussels. Successful strategies for achieving these goals should include consideration of

312 the natural capital available in the form of bivalve filter feeders, and ribbed mussels in particular.

313 The assumptions that we made for this study are most likely to result in an underestimate

314 of mussel change by 2050. By assuming that all pervious surfaces that will be within the future

315 tidal envelope will be suitable habitat for ribbed mussels almost certainly overestimates how

316 much habitat will be available in the future. We also had to hold several of the factors in the

317 model constant (cordgrass stem density, percent agriculture, and percent forest) for the future

318 given that we didn't have projections of how they were likely to change. Given that the only one

319 of those factors had a large impact on mussel density (cordgrass stem density), we don't expect

320 that minor to moderate changes in either forested or agricultural land cover in the proximal

321 upland are likely to have substantial effects on the density of ribbed mussels in the future. 
322 Further, our necessary assumption of zero shoreline armoring growth fails to account for the

323 additional coastal squeeze resulting in marsh loss that armoring growth will cause. This will be

324 especially true in areas of greater exposure, making the loss of these habitats even more acutely

325 felt given the greater densities of mussels found in higher exposure settings. Shorelines in

326 densely populated areas are also most likely to be armored for property protection (Kittinger and

327 Ayers 2010), making the loss of mussels even greater in urban areas, which have historically

328 struggled to reduce nutrient inputs to healthy levels in adjacent waters. Conversely, this work

329 also assumes a "bathtub" approach to SLR and marsh loss, which is often criticized for its

330 assumption of no vertical marsh accretion and therefore a greater estimate of marsh loss than

331 may be realistic (Passeri et al. 2015, Kirwan et al. 2016). Given that our approach to mussel

332 population change is focused on the waterward edge of the marsh and not on total areal extent,

333 we feel that our estimates of mussel population change may only be slightly tempered by this

334 assumption. The Chesapeake Bay is a microtidal, sediment-limited estuary with the second

335 highest rate of SLR in the country (Mitchell et al. 2017). Marshes in the Chesapeake Bay are

336 already well below the theoretical limits of marsh accretion that would allow them to keep up

337 with SLR as a result of current rates of SLR and low levels of suspended sediment (Kirwan et al.

338 2010), making it unlikely that marsh accretion will have substantial moderating effects on marsh

339 and mussel loss throughout the lower Chesapeake Bay. Therefore, it is likely that our

340 assumptions have resulted in a fairly conservative estimate of change, and expect that the actual

341 change may be considerably larger.

\section{CONCLUSIONS}

343 Ribbed mussels are an integral part of the US Atlantic coast saltmarsh ecosystem. The

344 mutualistic relationship between ribbed mussels and cordgrass promotes the stability and 
345 functionality of these ecosystem service-rich habitats. Given their aggregation along the front

346 edge of the marsh, where SLR and erosion will have their biggest impacts, understanding where

347 and how mussel populations are most likely to change in the future provides key insights into

348 their resulting loss or gain of services. In systems like the Chesapeake Bay where water quality is

349 poor due to anthropogenic inputs, and relative SLR is high, these changes in mussel abundance

350 and distribution are likely to have noticeable impacts on the surrounding environment. Our study

351 has demonstrated that the ribbed mussel population will not respond homogeneously throughout

352 the Chesapeake Bay, with clear areas of gains and losses. Preparing for and adapting to the

353 impacts of climate change and sea level rise must involve a comprehensive understanding of how

354 changes in existing natural capital will impact our ecosystem restoration goals.

356 ACKNOWLEDGMENTS

357 The authors would like to acknowledge Julie Herman and Molly Mitchell for providing 358 the projections of marsh extent in 2050. This manuscript was much improved by the insightful 359 comments of Roger Mann, Megan La Peyre, Randolph Chambers, Matthias Leu, Taryn Sudol, 360 Linda Blum, and two anonymous reviewers. Funding for this project was provided by the Office 361 of the Associate Dean of Academic Studies at the Virginia Institute of Marine Science and NSF 362 Coastal SEES award \#1600131. This paper is Contribution No. 3926 of the Virginia Institute of

363 Marine Science, William \& Mary. 


\section{Literature Cited}

365 Angelini, C., J. N. Griffin, J. van de Koppel, L. P. M. Lamers, A. J. P. Smolders, M. DerksenHooijberg, T. van der Heide, and B. R. Silliman. 2016. A keystone mutualism underpins resilience of a coastal ecosystem to drought. Nature Communications 7:12473.

Angelini, C., T. van der Heide, J. N. Griffin, J. P. Morton, M. Derksen-Hooijberg, L. P. M. Lamers, A. J. P. Smolders, and B. R. Silliman. 2015. Foundation species’ overlap enhances biodiversity and multifunctionality from the patch to landscape scale in southeastern United States salt marshes. Proceedings of the Royal Society B: Biological Sciences 282:20150421.

Baker, P., and R. Mann. 2003. Late stage bivalve larvae in a well-mixed estuary are not inert particles. Estuaries 26:837-845.

Bertness, M. D. 1984. Ribbed mussels and Spartina alterniflora production in a New England salt marsh. Ecology 65:1794-1807.

Bertness, M. D., and E. Grosholz. 1985. Population dynamics of the ribbed mussel, Geukensia demissa: The costs and benefits of an aggregated distribution. Oecologia 67:192-204.

Bertness, M. D., and G. H. Leonard. 1997. The role of positive interactions in communities: lessons from intertidal habitats. Ecology 78:1976-1989.

Bilkovic, D. M., M. M. Mitchell, R. E. Isdell, M. Schliep, and A. R. Smyth. 2017. Mutualism between ribbed mussels and cordgrass enhances salt marsh nitrogen removal. Ecosphere

384 Bilkovic, D. M., M. Mitchell, P. Mason, and K. Duhring. 2016. The role of living shorelines as 385 estuarine habitat conservation strategies. Coastal Management 4:161-174. 
Boon, J. D. 2012. Evidence of sea level acceleration at U.S. and Canadian tide stations, Atlantic Coast, North America. Journal of Coastal Research:1437-1445.

Boon, J. D., and M. Mitchell. 2015. Nonlinear change in sea level observed at North American tide stations. Journal of Coastal Research:1295-1305.

Center for Coastal Resources Management (CCRM). 2018. Virginia Shoreline Inventory.

Diaz, R. J., and R. Rosenberg. 2008. Spreading dead zones and consequences for marine ecosystems. Science 321:926-929.

ESRI. 2017. ArcMap. Environmental Systems Research Institute, Redlands, CA.

Fagherazzi, S., S. C. Anisfeld, L. K. Blum, E. V. Long, R. A. Feagin, A. Fernandes, W. S.

Ermgassen, P. S. E. zu, M. D. Spalding, R. E. Grizzle, and R. D. Brumbaugh. 2013. Quantifying the loss of a marine ecosystem service: filtration by the eastern oyster in US estuaries. Estuaries and Coasts 36:36-43. Kearney, and K. Williams. 2019. Sea level rise and the dynamics of the marsh-upland boundary. Frontiers in Environmental Science 7.

Franz, D. R. 2001. Recruitment, survivorship, and age structure of a New York ribbed mussel population (Geukensia demissa) in relation to shore level—a nine year study. Estuaries 24:319-327.

Galimany, E., J. M. Rose, M. S. Dixon, and G. H. Wikfors. 2013. Quantifying feeding behavior of ribbed mussels (Geukensia demissa) in two urban sites (Long Island Sound, USA) with different seston characteristics. Estuaries and Coasts 36:1265-1273. 
Grabowski, J. H., R. D. Brumbaugh, R. F. Conrad, A. G. Keeler, J. J. Opaluch, C. H. Peterson, M. F. Piehler, S. P. Powers, and A. R. Smyth. 2012. Economic valuation of ecosystem services provided by oyster reefs. BioScience 62:900-909.

Hardaway, Jr., C. S., D. A. Milligan, and C. A. Wilcox. 2017. Shoreline Studies Program shoreline evolution database.

Henley, J. 2006. Huc12 -- Watershed Boundary Dataset for 12-Digit Hydrologic Units. US Geological Survey, Reston, VA.

Honig, A., J. Supan, and M. L. Peyre. 2015. Population ecology of the gulf ribbed mussel across a salinity gradient: recruitment, growth and density. Ecosphere 6:1-13.

IPCC. 2014. Part A: Global and Sectoral Aspects. Contribution of Working Group II to the Fifth Assessment Report of the Intergovernmental Panel on Climate Change. Page 1132 in C. B. Field, V. R. Barros, D. J. Dokken, K. J. Mach, M. D. Mastrandrea, T. E. Bilir, M. Catterjee, and Y. O. Ebi, editors. Climate Change 2014: Impacts, Adaptation, and Vulnerability. Cambridge University Press, Cambridge, United Kingdom and New York, NY, USA.

Isdell, R. E., D. M. Bilkovic, and C. H. Hershner. 2018. Shorescape-level factors drive distribution and condition of a salt marsh facilitator (Geukensia demissa). Ecosphere 9:e02449.

Jordan, T. E., and I. Valiela. 1982. A nitrogen budget of the ribbed mussel, Geukensia demissa, and its significance in nitrogen flow in a New England salt marsh. Limnology and Oceanography 27:75-90.

Julien, A. R., A. W. Tweel, D. J. Mcglinn, G. W. Sundin, N. H. Hadley, and P. R. KingsleySmith. 2019. Characterization of ribbed mussel, Geukensia demissa (Dillwyn, 1817), 

habitat in relation to tidal elevation and salinity in a South Carolina estuary. Journal of Shellfish Research 38:53-61.

434 Kellogg, M. L., A. R. Smyth, M. W. Luckenbach, R. H. Carmichael, B. L. Brown, J. C.

435 Cornwell, M. F. Piehler, M. S. Owens, D. J. Dalrymple, and C. B. Higgins. 2014. Use of 436 oysters to mitigate eutrophication in coastal waters. Estuarine, Coastal and Shelf Science $151: 156-168$.

Kemp, W. M., W. R. Boynton, J. E. Adolf, D. F. Boesch, W. C. Boicourt, G. Brush, J. C. Cornwell, T. R. Fisher, P. M. Glibert, J. D. Hagy, L. W. Harding, E. D. Houde, D. G. Kimmel, W. D. Miller, R. I. E. Newell, M. R. Roman, E. M. Smith, and J. C. Stevenson. 2005. Eutrophication of Chesapeake Bay: historical trends and ecological interactions.

443 Kirwan, M. L., G. R. Guntenspergen, A. D’Alpaos, J. T. Morris, S. M. Mudd, and S. Temmerman. 2010. Limits on the adaptability of coastal marshes to rising sea level. Geophysical Research Letters 37:L23401.

Kirwan, M. L., S. Temmerman, E. E. Skeehan, G. R. Guntenspergen, and S. Fagherazzi. 2016.

449 Kittinger, J. N., and A. L. Ayers. 2010. Shoreline armoring, risk management, and coastal resilience under rising seas. Coastal Management 38:634-653.

451 Kreeger, D. A., and R. I. E. Newell. 2001. Seasonal utilization of different seston carbon sources 452 by the ribbed mussel, Geukensia demissa (Dillwyn) in a mid-Atlantic salt marsh. Journal of Experimental Marine Biology and Ecology 260:71-91. 
454 Lent, C. M. 1969. Adaptations of the ribbed mussel, Modiolus demissus (Dillwyn), to the $455 \quad$ intertidal habitat. American Zoologist 9:283-292.

456 Leonard, L. A., and A. L. Croft. 2006. The effect of standing biomass on flow velocity and 457 turbulence in Spartina alterniflora canopies. Estuarine, Coastal and Shelf Science 69:325-336.

459 Linker, L. C., R. A. Batiuk, G. W. Shenk, and C. F. Cerco. 2013. Development of the Chesapeake Bay watershed total maximum daily load allocation. JAWRA Journal of the

462 Loosanoff, V. L., and H. C. Davis. 1963. Rearing of bivalve mollusks. U.S. Bureau of Commercial Fisheries Biological Laboratory, Milford, Connecticut, USA.

464 Mitchell, M., J. Herman, D. M. Bilkovic, and C. Hershner. 2017. Marsh persistence under sea465 level rise is controlled by multiple, geologically variable stressors. Ecosystem Health and Sustainability $3: 1379888$.

Moody, J., and D. Kreeger. 2020a. Ribbed mussel (Geukensia demissa) filtration services are driven by seasonal temperature and site-specific seston variability. Journal of Experimental Marine Biology and Ecology 522:151237.

471 Filtration Rates Across the Salt Marsh Landscape. Estuaries and Coasts.

472 Passeri, D. L., S. C. Hagen, S. C. Medeiros, M. V. Bilskie, K. Alizad, and D. Wang. 2015. The 473 dynamic effects of sea level rise on low-gradient coastal landscapes: A review. Earth's $474 \quad$ Future 3:159-181.

475 Pontee, N. 2013. Defining coastal squeeze: A discussion. Ocean \& Coastal Management 84:204476 207. 
477 R Development Core Team. 2011. R: A language and environment for statistical computing. R $478 \quad$ Foundation for Statistical Computing, Vienna, Austria.

479 Scheltema, R. S. 1986. On dispersal and planktonic larvae of benthic invertebrates: An eclectic $480 \quad$ overview and summary of problems. Bulletin of Marine Science 39:290-322.

481 Schuerch, M., A. Vafeidis, T. Slawig, and S. Temmerman. 2013. Modeling the influence of 482 changing storm patterns on the ability of a salt marsh to keep pace with sea level rise. 483 Journal of Geophysical Research-Earth Surface 118:84-96.

484 Torio, D. D., and G. L. Chmura. 2013. Assessing coastal squeeze of tidal wetlands. Journal of $485 \quad$ Coastal Research:1049-1061.

486 US Environmental Protection Agency. 2010. Chesapeake Bay Total Maximum Daily Load for 487 nitrogen, phosphorus and sediment.

488 USACE. 2014. Final feasibility report and integrated environmental assessment: main report; 489 Lynnahaven river basin ecosystem restoration, Virginia Beach, Virginia. Pages 1-283.

490 Vogel, S. 1994. Life in moving fluids: The physical biology of flow. Princeton University Press.

491 Wright, R. T., R. B. Coffin, C. P. Ersing, and D. Pearson. 1982. Field and laboratory

492 measurements of bivalve filtration of natural marine bacterioplankton. Limnology and $493 \quad$ Oceanography 27:91-98. 


\section{TABLe HeAdingS}

496 Table 1 - Ecosystem service rates used for mussel service contributions. In the "Rate" column, 497 Sp is the Spring rate, Su is Summer, and F is Fall/Autumn. 
498 Table 1 -

\begin{tabular}{|c|c|c|c|c|}
\hline Service & Source & & Rate & Units $^{499}$ \\
\hline Filtration & Kreeger et al. (2018) & & 5.01 & $\mathrm{~L} \cdot \mathrm{h}^{-1} \cdot \mathrm{G}^{-1}$ \\
\hline \multirow[t]{3}{*}{ Biodeposition } & Jordan and Valiela (1982) & $\mathrm{Sp}$ & $29.8(w t)^{0.839}$ & $\mu \mathrm{g} \mathrm{N} \cdot \mathrm{h}^{-1} \cdot \mathrm{g}^{-1}$ \\
\hline & & $\mathrm{Su}$ & $78.0(w t)^{0.856}$ & $\mu \mathrm{g} \mathrm{N} \cdot \mathrm{h}^{-5} \cdot \mathrm{g}^{1}$ \\
\hline & & $\mathrm{F}$ & $24.5(w t)^{0.770}$ & $\mu \mathrm{g} \mathrm{N} \cdot \mathrm{h}^{-1} \cdot{ }^{-1} 2^{-1}$ \\
\hline Denitrification & Bilkovic et al. (2017) & & 12.92 & $\mu \mathrm{g} \mathrm{N} \cdot \mathrm{h}^{-1} \cdot \mathrm{g}^{-1}$ \\
\hline
\end{tabular}




\section{Figure CAPTIONS}

505 Figure 1- The study area was located in Virginia's portion of the Chesapeake Bay. Watershed boundaries used for this study are outlined in black. State boundaries are indicated by a

Figure 2 - The total number of mussels (millions, M) within a given watershed in 2018 (A) and 2050 (B). Abundance estimates were derived from the spatial application of the mussel

Figure 3 - The front edge of the marsh throughout some sections of the study area is currently (A) primarily restricted to bordering narrow creek channels. Future projections (B) open up the narrow channel and expand the potential edge to the highly crenulated upland boundary. Future projections include the marsh loss resulting from SLR, and the mussel distribution model applied to the projected water-ward edge of the marsh in 2050.

Figure 4 - Absolute (A, in millions [M]) and relative (B) change in mussel populations by watershed from 2018 to 2050 . Losses are in red, gains are in blue.

Figure 5 - Recursive regression tree illustrating the importance of soft features in the future tidal extent to mitigate the impacts of sea level rise on ribbed mussels. Watersheds with $<28 \%$ forested land cover in the future intertidal zone had the largest loss of mussels $(-58 \% \pm$

524 Figure 6 - Bar plot of ribbed mussel filtration and nutrient processing, summarized by watersheds with mussel gains vs. losses. 


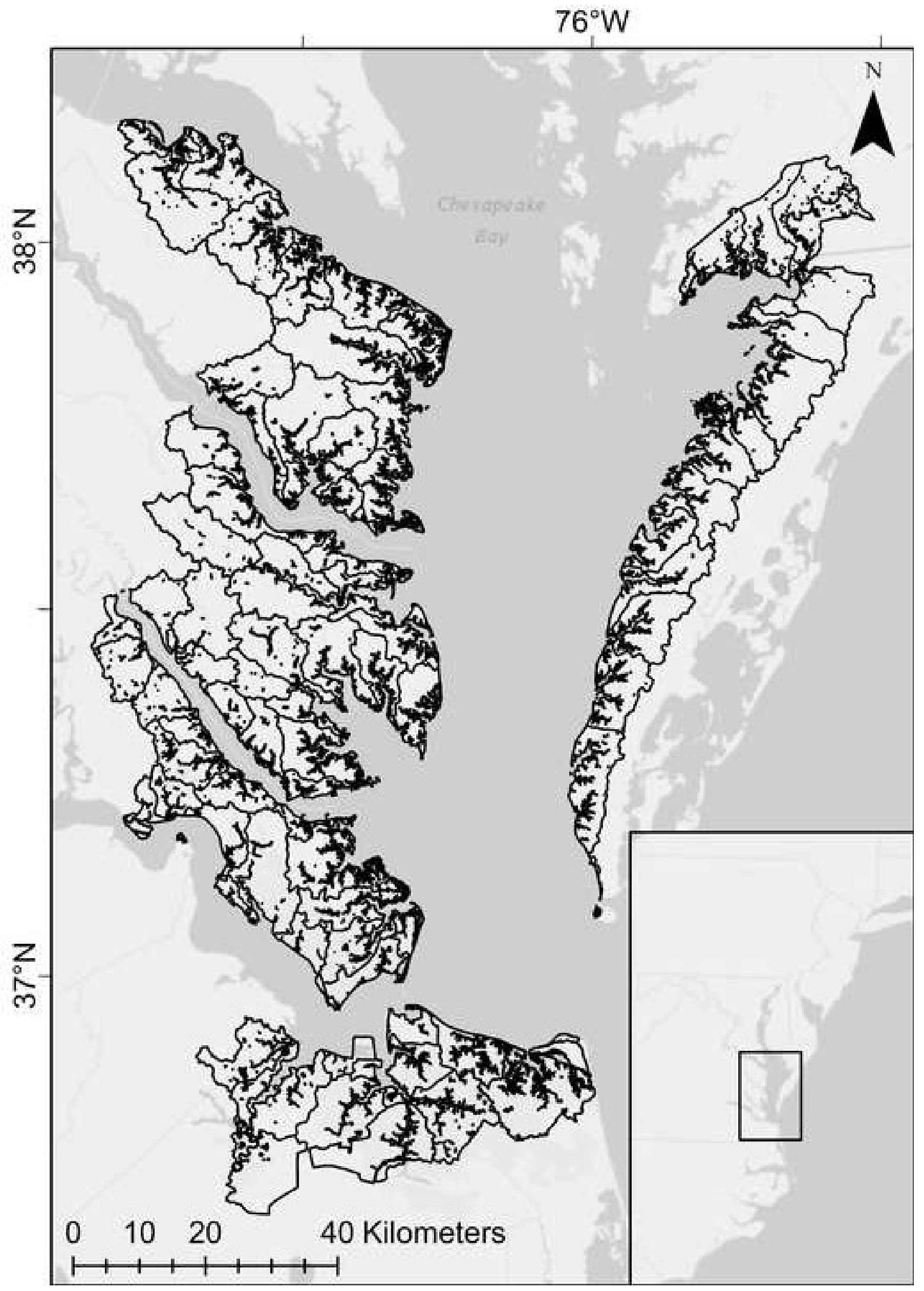



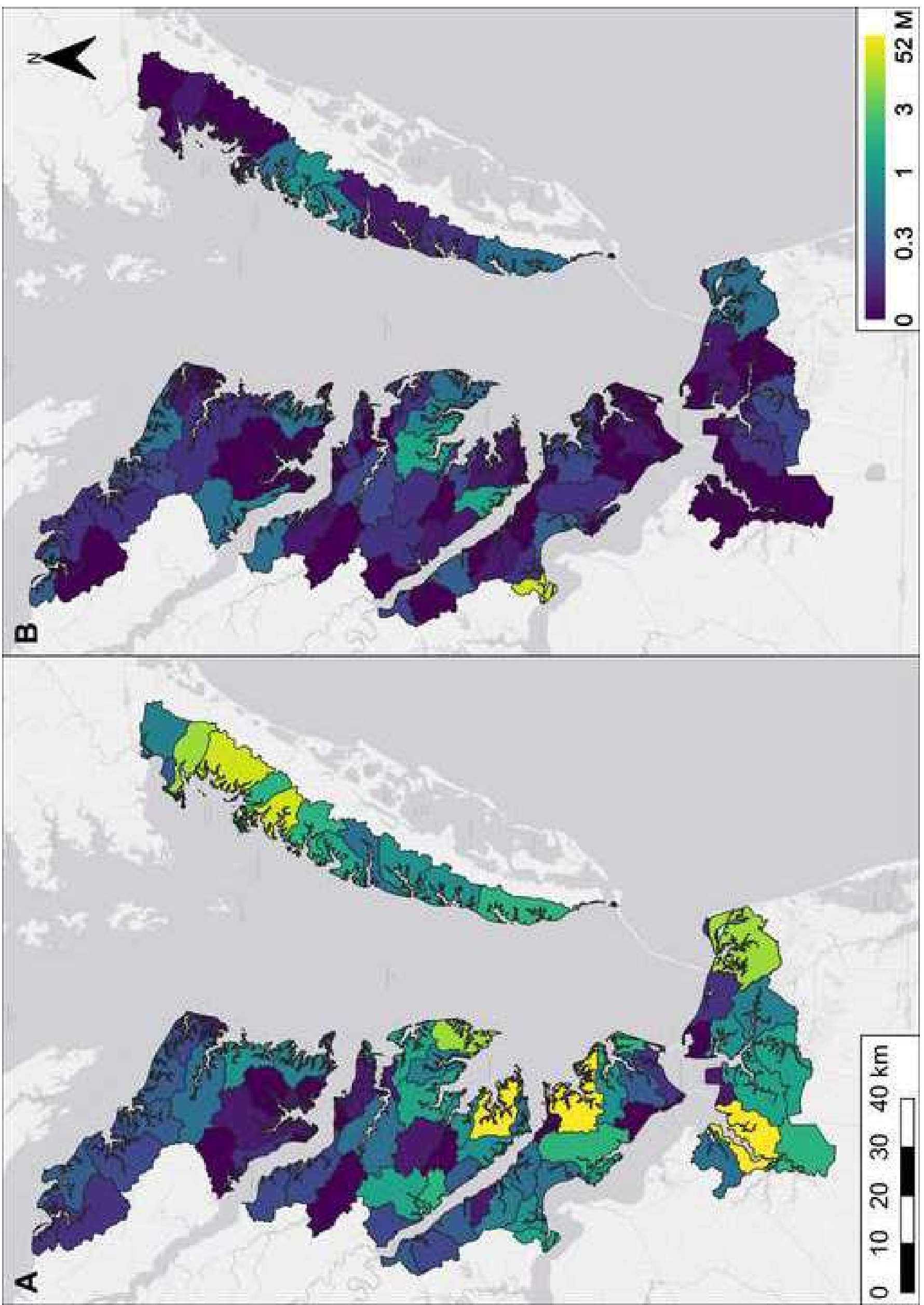


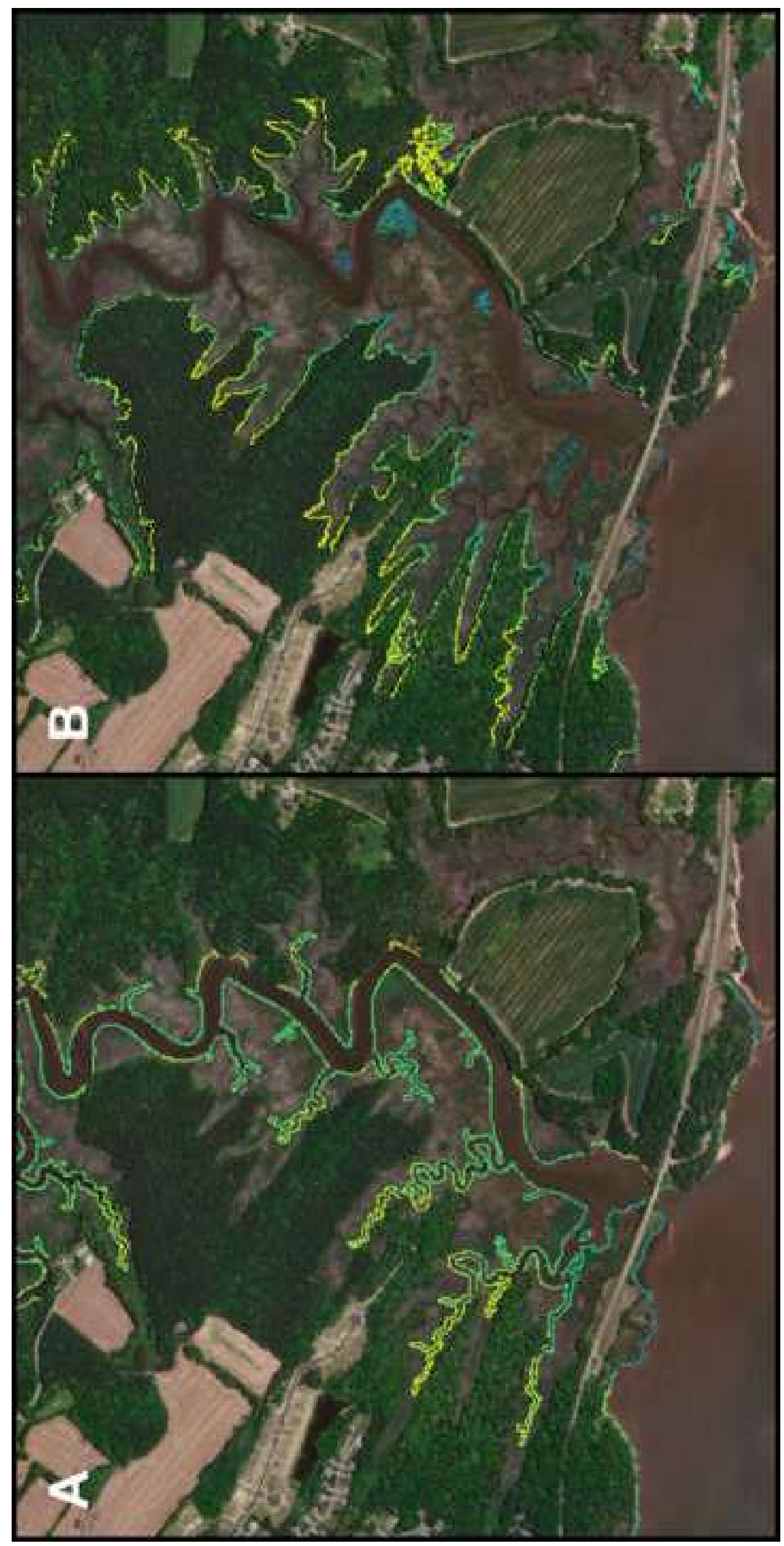

음 


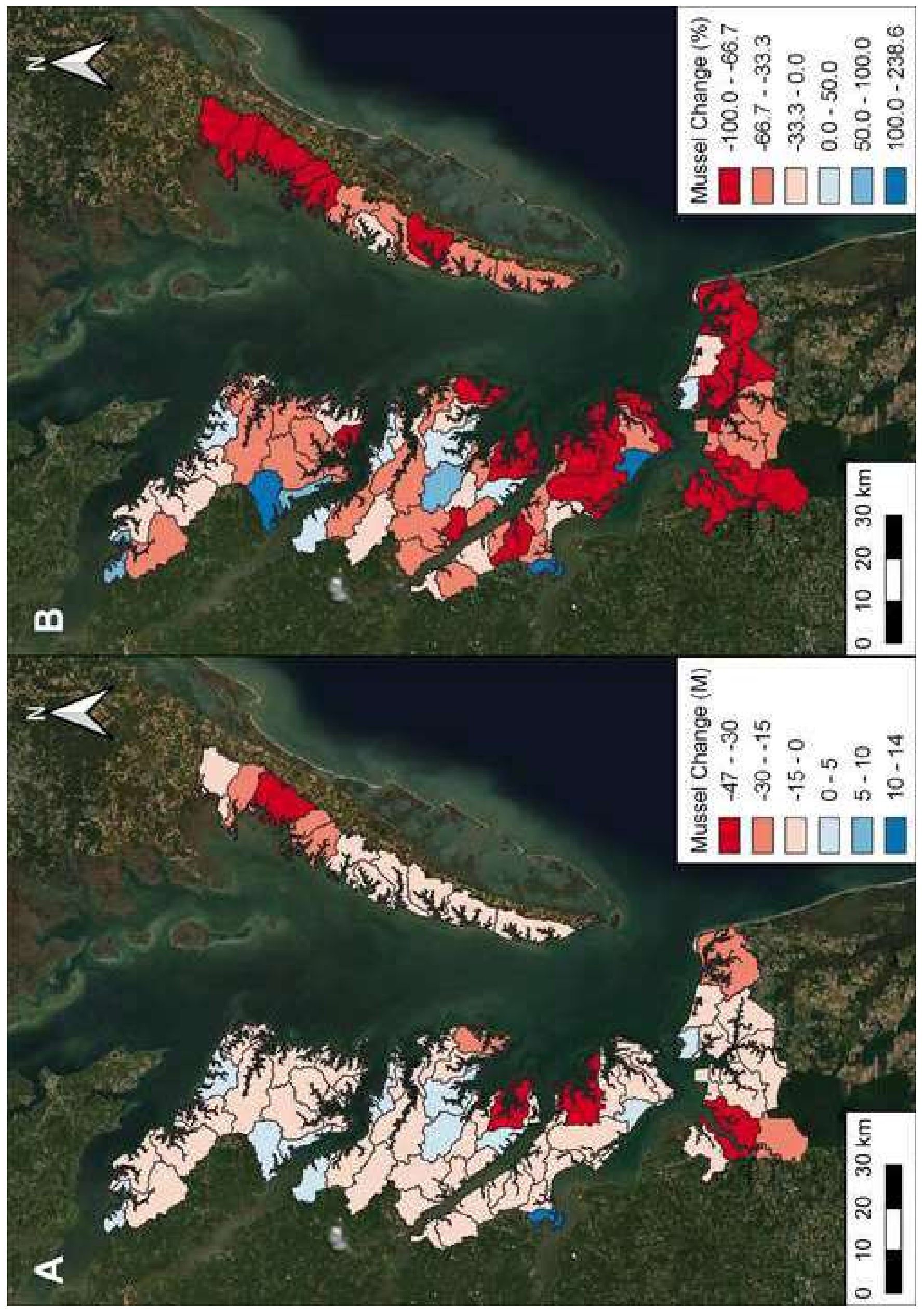




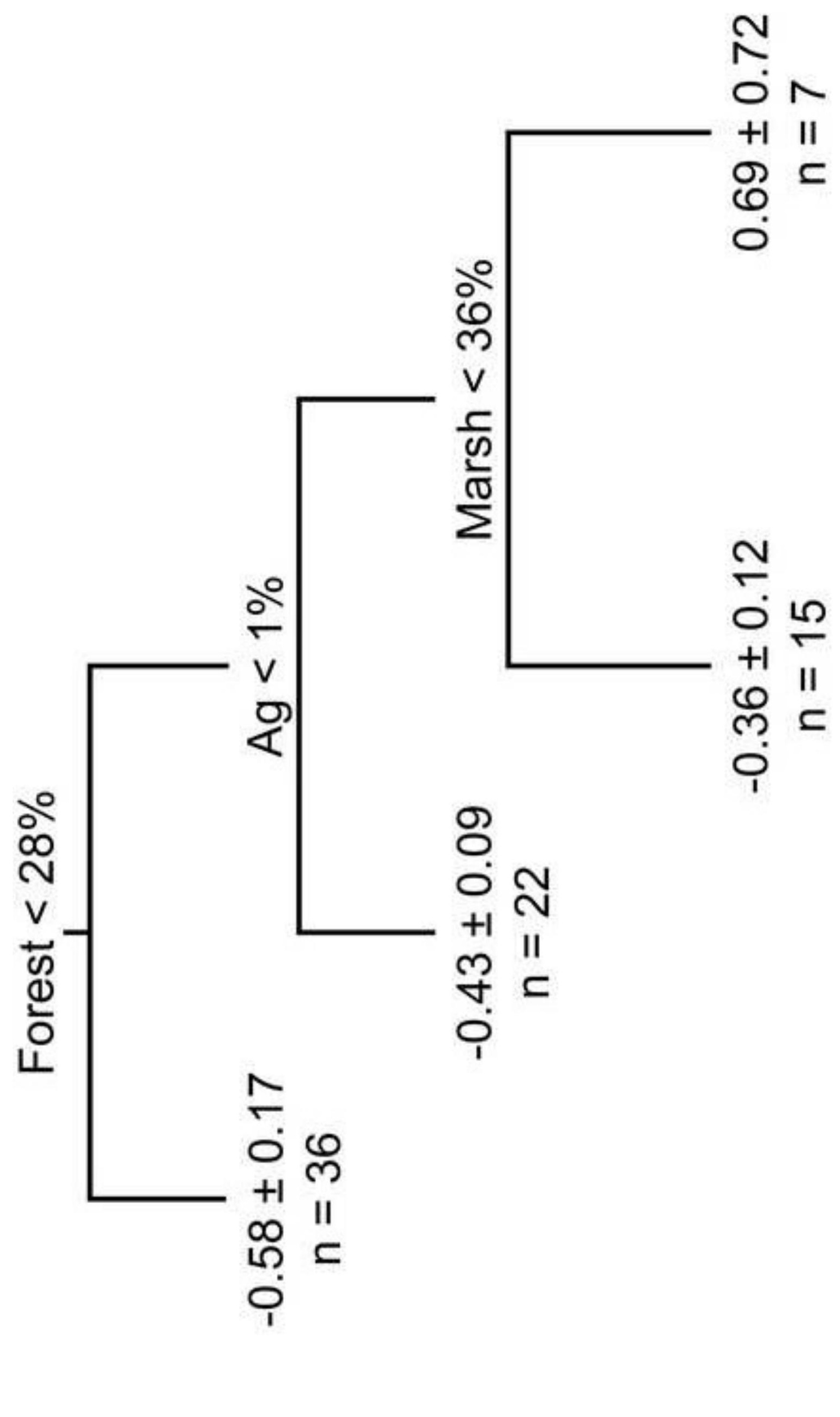



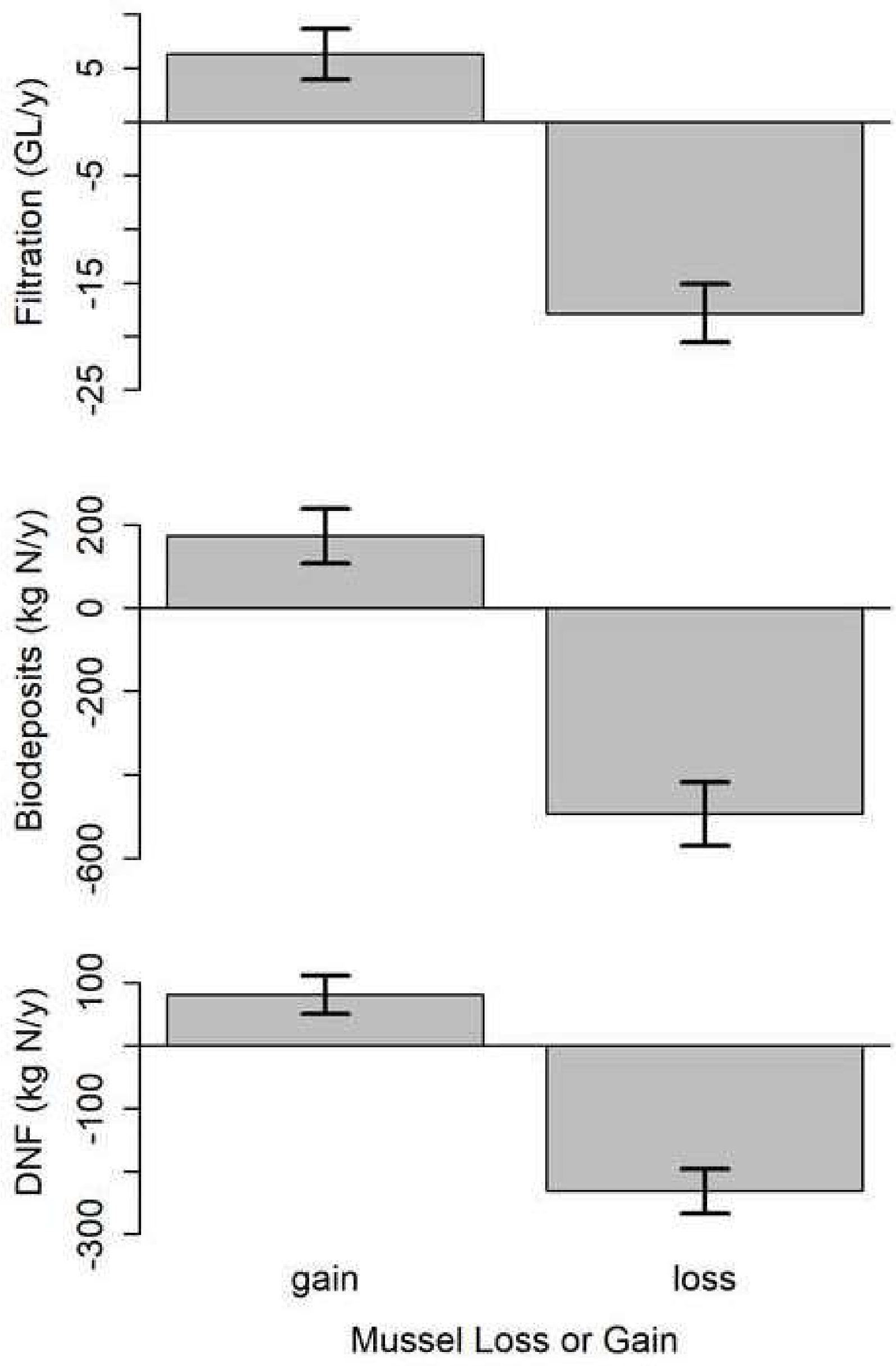